\title{
21. ORIGIN OF THE ABYSSAL BASALTIC SAND, SANDSTONE, AND GRAVEL FROM DSDP HOLE 396B, LEG 46
}

\author{
Henry J. B. Dick, Woods Hole Oceanographic Institution, Woods Hole Massachusetts \\ Jose Honnorez, Rosenstiel School of Marine and Atmospheric Science, Miami, Florida \\ and \\ Paul W. Kirst, Miami-Dade Community College, Miami, Florida
}

\section{INTRODUCTION}

Basaltic sand, sandstone, and gravel were recovered in three separate sub-basement beds from Hole 396B. Drilling in these beds was characterized by unusually high drilling rates and by sticking and jamming of the bit. This is, to our knowledge, the first time DSDP drilling has recovered such material from the sub-basement, although similar erratic drilling conditions have been reported at other DSDP sites. That the sands and gravels from Hole 396B are not drilling artifacts is indicated by exceptionally high drilling rates through the second sand bed $(43 \mathrm{~m} / \mathrm{hr}$ compared with 1 to 6 mph in basalt), very poor to nil core recovery in the sands, high-porosity logs, and the presence of bedded sandstone mixed with sand in Core 30 .

Recovery of these sands and gravels should not be surprising, however, because locally derived sands and gravels are common in the abyssal oceanic crust. Fox and Heezen (1965) have reported sands being found in sediments (obtained by gravity cores) from 24 different locations along the crest of the Mid-Atlantic Ridge.

\section{STRATIGRAPHY}

Sand and gravel were recovered in Core 19 (from 277.0 to $278.5 \mathrm{~m}$ sub-bottom), Core 30 (377.5 to $379.0 \mathrm{~m})$, and Core 31 (396.0 to $397.5 \mathrm{~m}$ ). As shown in the Hole Summary, the lower two cores are considered a part of a clastic zone.

Core 19 comes from the center of the Unit 4, which consists of a sequence of porphyritic pillow basalts. One $8-\mathrm{cm}$ piece of basalt was recovered with the sand and gravel, which was similar to that found throughout the rest of Unit 4. The sand from Core 19 was thought to be drilling cuttings and, accordingly, was not described in the site summary or Initial Core Description. Cores 18 and 20 (immediately above and below Core 19 , respectively) were drilled through a pillow basalt sequence including complete sections of a number of large pillows. Some lithified nannoplankton ooze (limestone) occurs in the interstices of these pillows, and calcite and zeolites occur as veins in some of the pillows. There is little or no evidence, however, for the presence of a calcite-cemented pillow breccia at this horizon in either Cores 18 or 20.

The drilling of the last 90 meters of Hole 396B was characterized by erratic drilling rates, poor core recoveries, and sticking and jamming of the drill string in the hole. Such behavior is usually encountered when drilling through gravels and rubbles. Sands, gravels, and breccias predominate the core recoveries in this interval, which is designated hereafter as "the clastic zone." The clastic zone is divided into four units: a breccia unit (Unit 5, 316.0 to $345.0 \mathrm{~m}$ sub-bottom, Cores 23 to 25 ), an upper basaltic gravel unit (Unit 6, 345.0 to $386.5 \mathrm{~m}$, Cores 26 to 31 ), a phyric pillow basalt unit (Unit 7, 386.5 to $396.0 \mathrm{~m}$, Core 32), and a lower basaltic gravel unit (Unit 8, 396.0 to $405.5 \mathrm{~m}$, Core 33).

The breccia unit (Unit 5) consists of an association of pillow breccias and volcaniclastic breccias, both cemented by zeolite and carbonate. The basalt from the pillow fragments is generally more weathered than the overlying porphyritic basalt from Unit 4 . The volcaniclastic breccia is composed of poorly to moderately sorted gravel to sandsized chips of glass, a few fragments of intersertal aphyric basalt, and rare olivine and plagioclase grains. A $15-\mathrm{cm}$ long section of bedded glass breccia was also recovered. The glass breccia is cemented with carbonate and zeolite which coat the grains, often leaving incompletely filled vugs and interstices. The glass fragments are angular and generally are altered completely to palagonite; fresh glass, if found, occurs only in the cores of larger grains.

The upper gravel unit (Unit 6) was recovered in Cores 26, 28 and 30 . Cores 26 and 28 contained three basalt fragments similar to those in the overlying pillow breccia. Core 30 contains $90 \mathrm{~cm}$ of sideromelane sand and gravel (Plate 1), one small pillow basalt (Plate 2), and two fragments of basaltic sandstone (Plate 3 ). The pillow basalt is $4 \mathrm{~cm}$ across and has a hollow core. Both its glassy rind and the intersertal inner part are fresh. The sandstone (Plate 3 ) essentially consists of silt to fine gravel-sized chips of fresh basaltic glass and plagioclase grains loosely cemented by smectites. The petrography of the sand is described in detail below.

The phyric pillow basalt unit (Unit 7, Core 32) contains phyric to sparsely phyric basalt. The basalt is less altered than that in the clastic unit; breccia fragments are absent, suggesting that this may not be a rubble unit.

The lower basaltic gravel (Unit 8 , Core 33 ) contains only fine gravel and sand. It is described in detail below.

\section{WELL LOGS AND DRILLING RATES}

A valuable source of information for stratigraphic interpretation of the Hole $396 \mathrm{~B}$ drilling results is the well logs and penetration rates. The penetration rate $(3.1 \mathrm{~m} / \mathrm{hr})$ and well logs for the approximate interval of Core 19 were similar to those for the porphyritic pillow basalt sequence (drilling rate averaged $3.4 \pm 1.0 \mathrm{~m} / \mathrm{hr}$ ) found above and below Core 19. It is important to note that a withdrawal and reentry of the drill string into the hole was made immediately before Core 19 was taken. The penetration rate for the clastic zone (Units 5 to 8), however, was high and erratic (av- 
eraging $11.7 \pm 11.5 \mathrm{~m} / \mathrm{hr}$ ) and there were abrupt discontinuities in all the well logs in the approximate area of the top of the clastic zone. The well logs appear to indicate a greater porosity (neutron $\log$ ), a reduced density (gammagamma $\log$ ), and a reduced sonic velocity (sonic velocity log) throughout the clastic zone. A second abrupt change occurs in the well logs at about 345 meters when the sonic velocity log and gamma-gamma log drop off-scale and the dual induction $\log$ (resistivity) decreases markedly. The sand and gravel in Core 30 (Unit 6) are from this interval. The penetration rate for Core 30 was $42.9 \mathrm{~m} / \mathrm{hr}$.; essentially, this is as fast as the drill string was lowered. No well logs went as deep as Cores 32 and 33; however, the drilling rate for Core $33(3.9 \mathrm{~m} / \mathrm{hr})$ was similar to that found for basalt.

\section{PETROGRAPHY OF SAND AND GRAVEL UNITS (UNITS 5, 6, AND 8)}

We have assumed that washing in the core liner during drilling and recovery procedures would have completely disrupted any primary stratigraphic features. Each sand and gravel core, therefore, was sampled at $15-\mathrm{cm}$ intervals along its length to insure a representative sampling of all size fractions. These samples then were combined for each core, sieved to standard size fractions, weighed, and mounted in epoxy for thin-sectioning.

A modal analysis for each size fraction was made by identifying and counting, under the microscope, all the grains in view at low-power magnification along a series of parallel traverses (1 $\mathrm{mm}$ apart) across the thin sections. Three thin sections were prepared for the coarser grained fractions. The average composition for each sand unit was calculated from the composition of each size fraction, weighted according to their weight percentage in the total sample of each sand unit. The modal composition of each sand unit is given in Table 1 and in histograms in Figures 1 and 2 .

Size distribution data for each core are plotted in Figure 3. All three cores contain pebble sand based on the Niggli (1952) classification scheme. As seen from Figure 3, the pebble sand in Core 19 is much more poorly sorted than in Cores 30 and 33, and has a positively skewed size distribution. Pebble sands in Cores 30 and 33 have a slightly negatively skewed size distribution and are well-sorted (although Section 30-1 is finer grained).

Each of the sands is unique in composition and sedimentological character.

The sand and gravel from Core 19 (Unit 4) are composed mainly of relatively crystalline basalt fragments, and phyric basalt and glass fragments are less common than in either Core 30 or 33 . Unlike the other sands, many of the basalt fragments are moderately weathered, generally having a buff color while some of the others appear fresh and recently broken. This is the only sand in which palagonitized glass is a significant constituent. Foraminifers constitute 5 per cent of the sand in Core 19, whereas they were absent from the sands in Cores 30 and 33 with the exception of a single foraminifer in Core 33. Granular holocrystalline basalt or diabase fragments, similar to that found in the relatively coarse-grained "cooling unit" (Unit 3 ) higher in the hole, were also common in the Core 19 sand. Although not a major constituent, calcite-cemented microbreccia was found among the clastic fragments, indicating the presence of at least some secondary reworked material. The grains are all angular.

The sand and gravel in Core 30 (Unit 6) consist of angular fragments of glass, variolitic glass, and cryptocrystalline and intersertal basalt. Two-thirds of the sand consist of glass

TABLE 1

DSDP Leg 46 Hole 396B Sand and Gravel Grain Counts

\begin{tabular}{|c|c|c|c|c|c|c|c|c|c|c|c|c|c|c|c|c|c|c|c|c|}
\hline \multirow{2}{*}{$\frac{\text { Sample No. }}{\text { Size Fraction (mm) }}$} & \multirow[b]{2}{*}{$<0.25$} & \multicolumn{3}{|c|}{ 396B-19-1 (101 g) } & \multirow[b]{2}{*}{$2-4$} & \multirow[b]{2}{*}{$>4$} & \multirow{2}{*}{$\begin{array}{l}\text { Weighted } \\
\text { Average }\end{array}$} & \multirow[b]{2}{*}{$<0.25$} & \multicolumn{3}{|c|}{$396 \mathrm{~B}-30-1(87 \mathrm{~g})$} & \multirow[b]{2}{*}{$>2$} & \multirow{2}{*}{$\begin{array}{l}\text { Weighted } \\
\text { Average }\end{array}$} & \multicolumn{6}{|c|}{$396 \mathrm{~B}-33-1(122 \mathrm{~g})$} & \multirow{2}{*}{$\begin{array}{l}\text { Weighted } \\
\text { Average }\end{array}$} \\
\hline & & $0.25 \overline{0.5}$ & $0.5-1$ & $1-2$ & & & & & $0.2 \overline{5-0.5}$ & $0.5-1$ & $1-2$ & & & $<0.25$ & $0.25 \overline{-0.5}$ & $0.5-1$ & $\overline{1.2}$ & $2-4$ & $>4$ & \\
\hline $\begin{array}{l}\text { Glass fragments } \\
\text { Aphyric }\end{array}$ & & & & & & & & & & & & & & & & & & & & \\
\hline $\begin{array}{l}\text { Aphyric } \\
\text { Olivine Phyric }\end{array}$ & & $\begin{array}{l}5.5 \\
0.5\end{array}$ & $\begin{array}{r}11.2 \\
0.7\end{array}$ & $\begin{array}{r}12.5 \\
0.9\end{array}$ & $\begin{array}{r}10.5 \\
0.7\end{array}$ & & $\begin{array}{r}11.0 \\
0.8\end{array}$ & & $\begin{array}{r}45.6 \\
2.7\end{array}$ & $\begin{array}{r}32.6 \\
7.0\end{array}$ & $\begin{array}{r}37.2 \\
3.2\end{array}$ & $\begin{array}{r}26.3 \\
3.3\end{array}$ & $\begin{array}{r}34.0 \\
5.0\end{array}$ & & $\begin{array}{r}25.0 \\
0.8\end{array}$ & $\begin{array}{r}19.5 \\
0.7\end{array}$ & $\begin{array}{r}15.7 \\
3.1\end{array}$ & $\begin{array}{r}14.4 \\
1.2\end{array}$ & & $\begin{array}{r}15.3 \\
2.1\end{array}$ \\
\hline Plagioclase phyric & & 0.6 & 0 & & 1.1 & & 1.0 & & 6.3 & 11.8 & 5.9 & 4.5 & 8.6 & & 2.5 & 2.8 & 3.5 & 4.1 & & 3.8 \\
\hline $\begin{array}{l}\text { Olivine and plagioclase } \\
\text { phyric }\end{array}$ & & & & & & & & & & & & & & & & & & & & \\
\hline $\begin{array}{l}\text { phyric } \\
\text { Variolitic glass }\end{array}$ & & 0.2 & 0.1 & 0.7 & 1.6 & & 0.8 & & 1.1 & 5.3 & 3.4 & 3.3 & 4.2 & & 0.8 & 0.7 & 1.7 & 1.7 & & 1.7 \\
\hline Aphyric & & 1.1 & 1.2 & 7.7 & 13.6 & & 7.8 & & 5.3 & 13.5 & 7.1 & 8.7 & 10.3 & & 4.5 & 7.8 & 12.2 & 10.2 & & 11.1 \\
\hline Olivine phyric & & 0 & 0 & 0.4 & 0 & & 0.1 & & 0.2 & 0 & 0.2 & 0.9 & 0.2 & & 0 & 0.7 & 1.3 & 0.2 & & 0.8 \\
\hline $\begin{array}{l}\text { Plagioclase phyric } \\
\text { Olivine and plagioclase }\end{array}$ & & 0.1 & 0.1 & 0.5 & 1.3 & & 0.7 & & 0.6 & 0 & 0.5 & 1.5 & 0.4 & & 0.2 & 0.9 & 0.9 & 2.4 & & 1.6 \\
\hline phyric & & 0 & 0 & 0 & 0.7 & & 0.2 & & 0 & 0 & 0.4 & 0.6 & 0.2 & & 0 & 0.9 & 2.2 & 2.2 & & 2.1 \\
\hline $\begin{array}{l}\text { Palagonitized glass } \\
\text { Intersertal basalt }\end{array}$ & & 3.4 & 4.4 & 10.5 & 5.8 & & 6.9 & & 0.9 & 0 & 1.6 & 2.4 & 0.9 & & 0.8 & 0.5 & 0.9 & 0.2 & & 0.6 \\
\hline Aphyric & & 30.8 & 43.8 & 44.3 & 45.6 & & 43.6 & & 14.5 & 9.0 & 14.8 & 26.6 & 13.4 & & 38.6 & 39.0 & 31.0 & 32.7 & & 32.2 \\
\hline Olivine phyric & & 0 & 0 & 0.2 & 0 & & 0.1 & & 0.3 & 0.8 & 0.5 & 3.6 & 1.0 & & 0.6 & 1.6 & 0.4 & 1.2 & & 0.8 \\
\hline $\begin{array}{l}\text { Plagioclase phyric } \\
\text { Olivine and plagioclase }\end{array}$ & 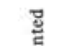 & 0.9 & 0.4 & 1.6 & 0.7 & 苞 & 0.9 & 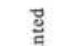 & 0.3 & 0.5 & 2.2 & 4.2 & 1.6 & 巴ृ & 2.5 & 5.0 & 6.1 & 10.5 & שֶ & 8.1 \\
\hline $\begin{array}{c}\text { phyric } \\
\text { Intergranular basalt }\end{array}$ & 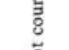 & 0.1 & 0.1 & 0.7 & 0.7 & $\frac{5}{8}$ & 0.5 & है & 0 & 1.0 & 0.8 & 2.1 & 1.0 & ¿ & 0.3 & 0.5 & 6.6 & 6.3 & 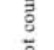 & 6.2 \\
\hline Aphyric & है & 4.1 & 8.2 & 8.1 & 6.9 & 茫 & 7.4 & z & 0 & 1.5 & 0.8 & 0.6 & 1.1 & z & 0.1 & 0.9 & 3.5 & 0 & zำ & 1.7 \\
\hline Olivine phyric & & 0 & 0 & 0 & 0 & & 0 & & $\mathbf{0}$ & 0 & 0 & 0.3 & - & & 0 & 0 & 0 & 0 & & 0 \\
\hline $\begin{array}{l}\text { Plagioclase phyric } \\
\text { Olivine and plagioclase }\end{array}$ & & 0.1 & 0.1 & 0.9 & 0 & & 0.3 & & 0 & 0 & 0 & 0.9 & 0.1 & & 0 & 0 & 2.6 & 0 & & 1.3 \\
\hline $\begin{array}{l}\text { phyric } \\
\text { Mineral Fragments }\end{array}$ & & 0 & 0 & 0.2 & 0 & & 0.1 & & 0 & 0 & 0 & 0 & 0 & & 0 & 0 & 0.9 & 0.2 & & 0.5 \\
\hline Olivine & & 1.1 & 0.3 & 0 & 0 & & 0.2 & & 1.7 & 0.3 & 0 & 0 & 0.2 & & 0.9 & 0.5 & 0 & 0 & & - \\
\hline Plagioclase & & 1.5 & 0.3 & 0 & 0.2 & & 0.3 & & 2.9 & 0.5 & 0.3 & 0 & 0.4 & & 6.8 & 0.5 & 0 & 0.2 & & 0.2 \\
\hline Clinopyroxene & & 0.2 & 0 & 0 & 0 & & - & & 0 & 0 & 0 & 0 & 0 & & 0 & 0 & 0 & 0 & & 0 \\
\hline Cryptocrystalline basalt & & 15.1 & 17.5 & 5.4 & 5.4 & & 8.9 & & 15.6 & 14.0 & 20.3 & 8.7 & 15.9 & & 9.7 & 11.5 & 3.9 & 3.9 & & 4.2 \\
\hline Calcite spherule & & 0.3 & 0.1 & 0.5 & 0.4 & & 0.4 & & 0.9 & 1.3 & 0.5 & 0.3 & 0.9 & & 3.3 & 2.3 & 0.9 & 0.2 & & 0.6 \\
\hline Microbreccia & & 0 & 0.4 & 1.6 & 0 & & 0.6 & & 0.9 & 1.0 & 0.5 & 1.2 & 0.8 & & 2.7 & 3.9 & 2.6 & 7.6 & & 5.0 \\
\hline Foraminifers & & 34.3 & 10.9 & 0 & 0 & & 5.1 & & 0 & 0 & 0 & 0 & 0 & & 0 & 0 & 0 & 0.2 & & 0.1 \\
\hline Fossiliferous limestone & & 0 & 0 & 1.8 & 1.1 & & 1.0 & & 0 & 0 & 0 & 0 & 0 & & 0 & 0 & 0 & 0 & & 0 \\
\hline Zeolite & & $\mathrm{nc}^{\mathrm{a}}$ & $\mathrm{nc}$ & ne & 1.8 & & 0.5 & & $\mathrm{nc}$ & nc & nc & $\mathrm{ne}$ & - & & ne & nc & $\mathrm{nc}$ & nc & & $\overline{-}$ \\
\hline Number of grains & & 438 & 681 & 569 & 447 & & 2135 & & 1163 & 399 & 1012 & 334 & 2908 & & 1065 & 436 & 537 & 410 & & 2448 \\
\hline Wt. \% sample & 1.2 & 6.4 & 19.5 & 29.1 & 30.2 & 13.6 & 85.2 & 0.5 & 2.4 & 47.3 & 38.4 & 11.4 & 99.5 & 0.4 & 1.0 & 2.6 & 44.7 & 43.1 & 8.5 & 91.1 \\
\hline
\end{tabular}



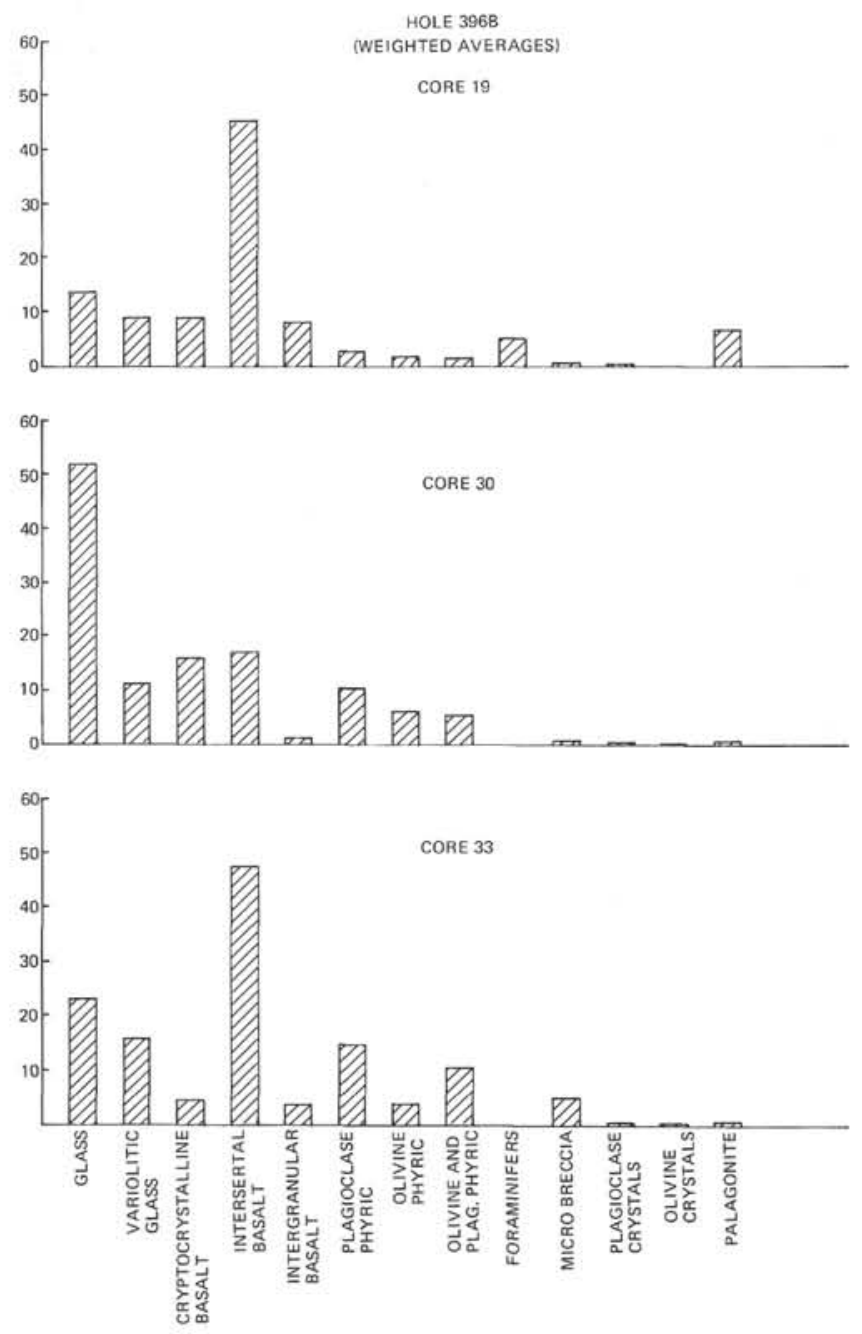

Figure 1. Histograms of the modal compositions of the sands and gravels from Cores 19, 30, and 33.

fragments, a much higher proportion than in the sand and gravel of either of the other cores under study. In addition, some olivine, plagioclase, and calcite grains were found. The basalt and glass fragments are generally unaltered, and only a few glass shards were palagonitized. A number of pieces of calcite-cemented microbreccia, and basalt fragments with calcite amygdule fillings and crosscutting veins again indicated the presence of authigenic minerals. One microbreccia fragment was found which was essentially identical in character to the larger sandstone fragments in the core (see below). No evidence of rounding of grains was seen, although the sand appears to be well sorted.

The sand and gravel in Core 33 (Unit 8) consist of the same kinds of lithic fragments as the other two. They contain more crystalline basalt fragments than the sand from Core 30 and more glass than the sand in Core 19 . Sixty per cent of the core consists of relatively crystalline basalt, so that, in degree of crystallinity, it resembles the sand in Core 19. The glass fragments are quite fresh and there is little palagonitized glass present. The basalt fragments are fresher in appearance than those in either Core 19 or Core 30. In fact, the basalt fragments most closely resemble freshly crushed road metal. Microbreccia fragments are more common $(5 \%)$ than in either of the other two sands and are
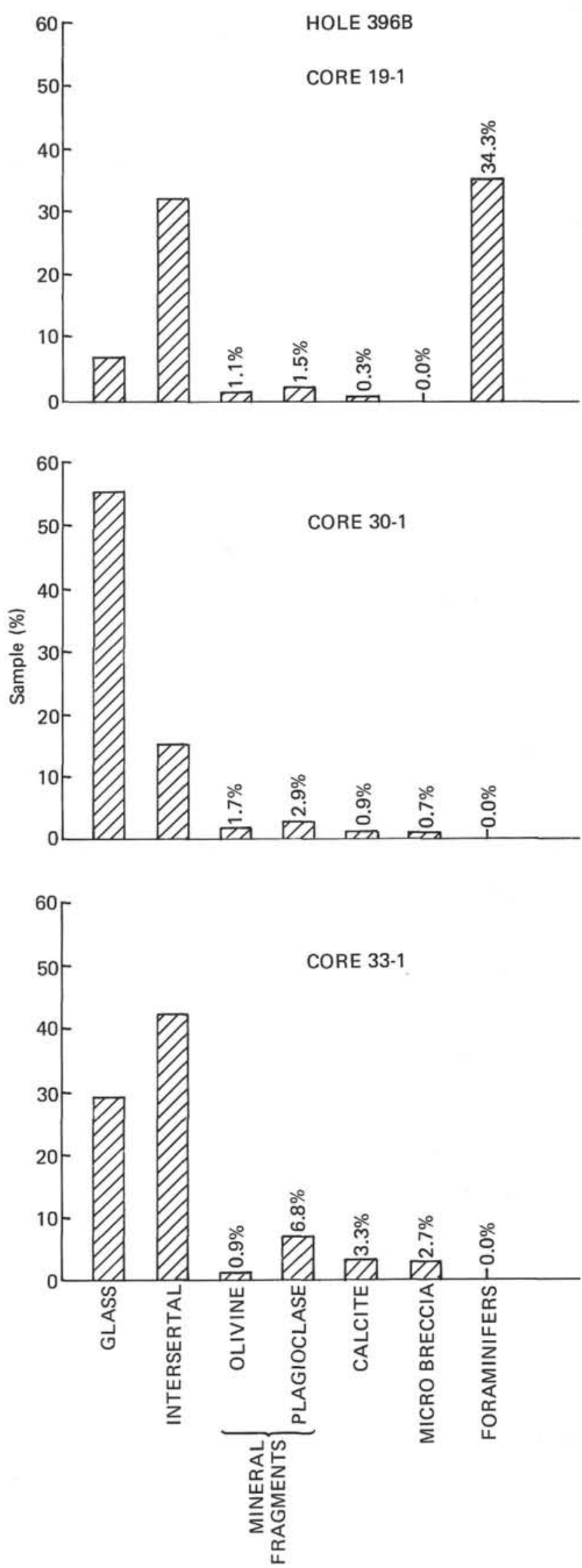

Figure 2. Histograms of the modal compositions of the 0.25 to 0.5 unit size fraction of the sands from Cores 19, 30 , and 33 . 

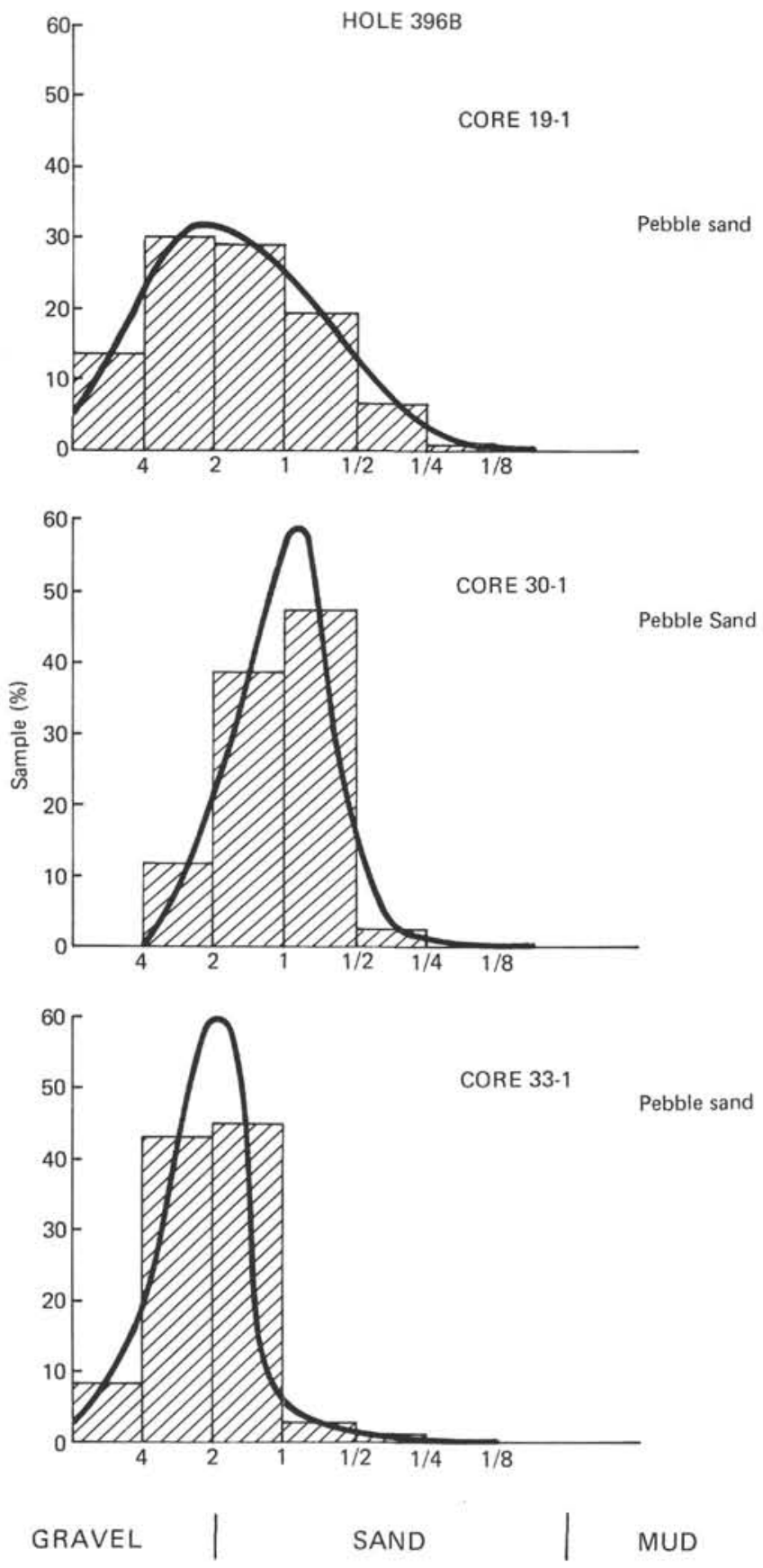

Figure 3. Grain size analysis of the sands and gravels from Cores 19, 30, and 33.

similar to the breccia in the volcaniclastic breccia unit. In several cases, fine-grained microbreccia adheres to the surfaces on the larger basalt grains. A single foraminifer was seen in the seven thin sections examined; none were seen in the loose sand and gravel. All the fragments are angular and, again, there is no evidence of rounding though the sand and gravel are moderately well sorted.

\section{PETROGRAPHY OF THE SANDSTONE FROM CORE 30}

The sample of sandstone from Core 30 that we have studied is dull brownish tan and displays two layers of contrasting grain size (Plate 3): a fine-grained graded-bedded layer made up by granules ranging from $0.15-0.20$ to 0.09 $0.12 \mathrm{~mm}$ in length; and a coarse-grained layer made up by grains ranging from 0.15 to $2.1 \mathrm{~mm}$ in length. The transition between both layers is extremely narrow: one can almost speak of a contact surface undulating between the much coarser grains of the coarse-grained layer, and the finest granules of the fine-grained layer. The latter are preferentially oriented with their largest dimension parallel to the contact between both layers.

The modal compositions of the fine-grained and the coarse-grained layers are presented in Table 2. Note the large volume of the pore spaces and the small amount of authigenic minerals cementing the grains together.

Angular shards of completely fresh basaltic glass are the major component of the sandstone, followed in importance by similarly shaped plagioclase and (more rarely) olivine grains. Palagonitized glass shards represent only a minor fraction of this rock, and a few variolitic glass granules are present. Intersertal basalt grains are present exceptionally in which one can identify plagioclase, clinopyroxene, and opaque mineral crystals. Both the fresh and palagonitized glass shards, and (less frequently) those of the other types, are coated with and cemented by a smectite layer ranging from 0.03 to $0.008 \mathrm{~mm}$ thick. Botryoidal concretions of Fe-Mn oxides(?) and smectites, and fibroradial aggregates of zeolite (probably phillipsite) are occasionally attached to the glassy granules. At very few places, a few glass and plagioclase shards are cemented together by a dark brown to opaque material tentatively identified as Fe-Mn oxides. Finally, we have observed a few foraminifers which look like members of the Alveolinidae or Mipgypsinidae families.

Using the methodology of (Honnorez and Kirst (1975) we employed two sets of morphometric parameters to discriminate between hyaloclastites (volcaniclastic rocks generated by non-explosive granulation of volcanic glass during quenching of basaltic magmas by water) and hyalotuffs (pyroclastic rocks generated by phreatomagmatic explosions of shallow submarine volcanoes). The granules making up these two volcaniclastic rock types plot in different portions of both: (1) a ternary diagram, the apexes of which represent the grain planarity $(\mathrm{P})$, convexity $(\mathrm{V})$, and concavity (C) percentages of the roundness according to Szadeczky-Kardoss (1933 in Krumbein and Pettijohn, 1938); and (2) a binary diagram relating the number of grain corners $(\mathrm{N})$ to their planarity $(\mathrm{P})$ percentage.

A morphometric analysis was conducted on the sandstone from Core 30 and $\mathrm{P}, \mathrm{V}$, and $\mathrm{C}$ percentages were measured for about 100 granules. One can see from Figure 4 that both

TABLE 2

Modal Composition of the Sandstone From Core 30 (Unit 6), Hole 396B, DSDP Leg 46

\begin{tabular}{lcc}
\hline & $\begin{array}{c}\text { Fine-Grained } \\
\text { Layer } \\
(\%)\end{array}$ & $\begin{array}{c}\text { Coarse-Grained } \\
\text { Layer } \\
(\%)\end{array}$ \\
\hline Fresh glass & 61 & 73 \\
Plagioclase and olivine & 7 & 6 \\
Palagonitized glass & 31 & 20 \\
Intersertal and variolitic glass & $<2$ & $<2$ \\
Total & 100 & 100 \\
Pore space & 43 & 34 \\
\hline
\end{tabular}




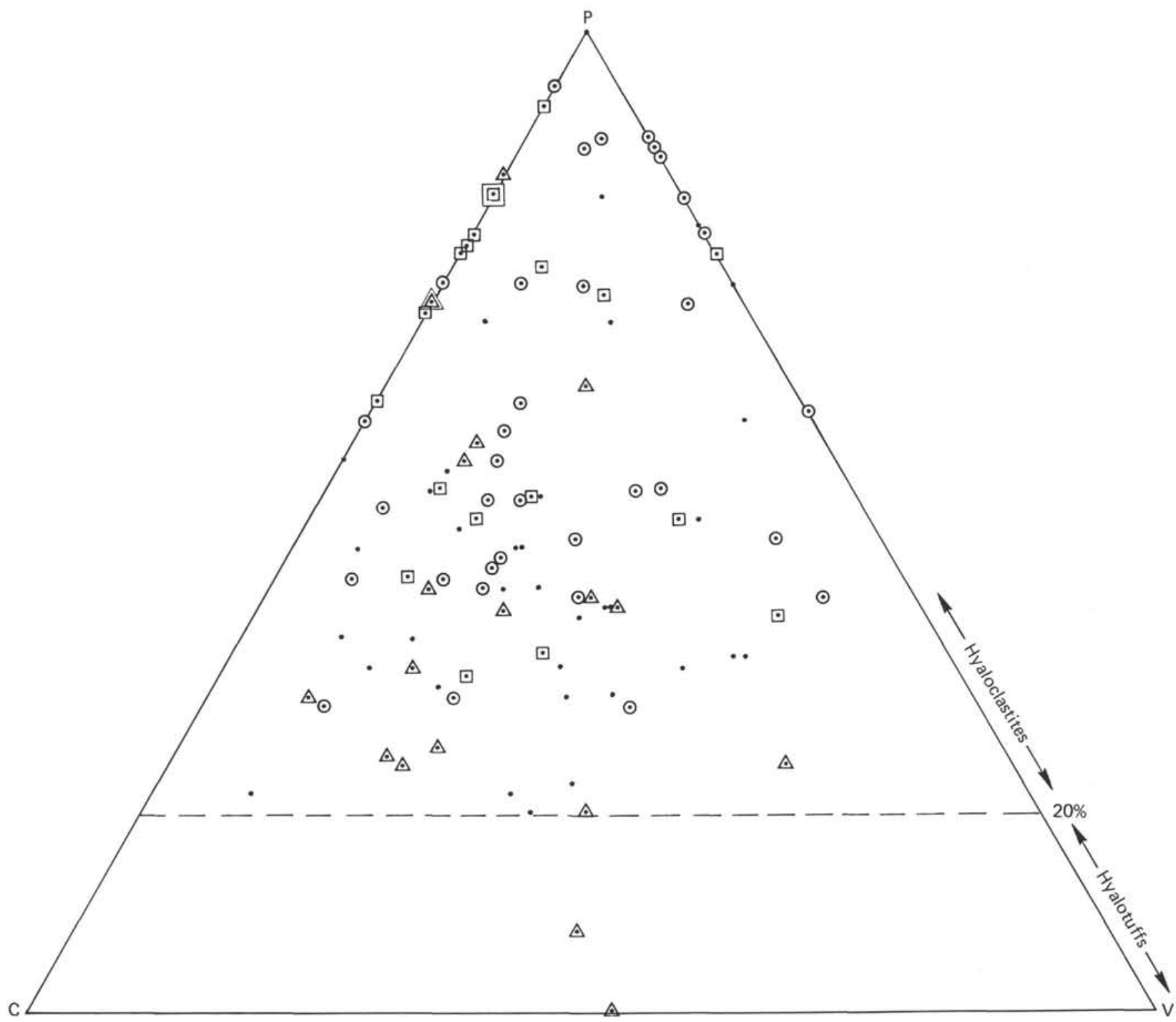

Figure 4. Planarity $(P)$, convexity $(V)$, and concavity $(C)$ teruary diagram of the sandstone from Core $30 . \cdot=$ plagioclase and olivine grains from the coarse-grained layer. $\odot=$ glass shards from the coarse-grained layer. $\triangle=$ plagioclase and olivine granules from the fine-grained layer. $\cdot=$ glass shards from the fine-grained layer.

plagioclase and glass granules in both the fine- and the coarse-grained layers plot above the 20 per cent C-V limit which separates the hyaloclastites from the hyalotuffs. We can infer, therefore, that the sandstone either is a hyaloclastite or has been generated by a non-explosive process similar to the spallation and granulation of thermally shocked glass during quenching.

\section{DISCUSSION}

The sands and gravels in Cores 19, 30, and 33 could have a wide range of possible origins (DSDP Scientific Party, Leg 46, 1976). These might include (1) drilling debris or lags formed of bits of rubble knocked or washed from the walls of the hole and concentrated at the bottom; (2) tectonic rubble and scree deposits along fault scarps; (3) hyaloclastites; (4) pyroclastic materials; and (5) any of the latter three types of clasts transported and deposited by bottom currents.

To further confuse the issue, each of the sands and gravels is different in physical appearance and composition; moreover, the penetration rates varied during their drilling recovery. The well logs also indicate significant differences between the different sands and gravels. For this reason, each is discussed separately.

The Core 19 sand and gravel is a heterogeneous mixture of fresh and palagonitized glass chips, weathered basalt clasts (some with what appear to be weathered broken surfaces), fresh basalt fragments (which appear to be recently broken and crushed), and bits of indurated nannofossil ooze (similar to that found between the interstices of many pillow basalts). Several lines of evidence suggest that the sand and gravel recovered in Core 19 did not come from a natural 
deposit. Instead, it appears to be a lag formed from a mixture of drilling debris (spalls and chips produced by drilling), microfossils concentrated from mud washed into the hole, and bits of rubble knocked off the walls of the hole. The principal evidence for such an origin is: (1) re-entry occurred prior to drilling and recovery of this core; (2) drilling rate and well logs are similar to that of the porphyritic basalt recovered above and below this core; (3) the microfossils in the sand and gravels span a long range of ages; and (4) intergranular basalt, a common lithic fragment in this sand, was drilled only in a short interval much higher in the hole. As might be expected, the sand represents a good average of the different lithic types encountered during drilling.

The sand and gravel recovered in Core 30 is very different from the Core 19 sand and gravel. We suggest that, in large part, it comes from an in situ horizon of basaltic sand and gravel or poorly lithified sandstone. There are a number of reasons for believing this to be the case:

1) Drilling rates and well logs suggest penetration of a dramatically more porous and less consolidated interval than either the overlying clastic breccia or the overburden of basalt above the clastic zone.

2) Several pieces of poorly cemented bedded sandstone composed of fresh glass and magmatic mineral fragments were found with the sand and gravel.

3) No re-entry occurred prior to recovery of the Core 30 sand and gravel.

4) The sand is compositionally different from the Core 19 sand, consisting predominantly of glass fragments as do the sandstone and the finer material in the overlying carbonate-cemented breccia. It is important to note that the sandstone recovered in Core 30 could be disaggregated easily by a light pounding. Thus, one may speculate that the sand and gravel might result from the disaggregation of the poorly consolidated sandstone. However, only a few chips of such sandstone were found in the sand and gravel, which is surprising if the sandstone were their source.

An estimate of the thickness of the sand and gravel can be guessed either on the basis of the well logs or on penetration rates. Anomalously high drilling rates were encountered only for Cores 30 and 31 , and for some 9.5 meters. The penetration rate in the clastic zone above these cores averaged a somewhat more conservative $7.3 \pm 2.3 \mathrm{~m} / \mathrm{hr}$, though twice greater than in the basalt sequence (averaging 3.6 $\pm 1.6 \mathrm{~m} / \mathrm{hr}$ ). On the other hand, the well logs suggest a 40-meter interval with roughly the same properties as in the area of Core 30 , capped by a 28-meter zone of somewhat less anomalogs material. It seems evident that the sand and gravel represent a significant horizon lying in a heterogeneous zone capped by a zone of basalt rubble and glassy breccia cemented by carbonate.

A comparison of the Core 30 sand and gravel to the sandstone and the carbonate-cemented breccia reveals that the former contain a much higher proportion of basalt lithic clasts. The sandstone is nearly entirely glass and magmatic fragments, while the carbonate-cemented breccia consists of large fragments of relatively crystalline basalt and finergrained glassy breccia. Many of the Core 30 basalt fragments appear to have been freshly broken and it seems likely that some of the drilling debris and in-fall from higher in the hole is mixed into the sand and gravel for this core.
The Core 30 sand and gravel, and the overlying breccia, may represent a talus breccia at the base of a fault scarp solutions. It seems reasonable that winnowing and current and/or a fissure in-filling. A crude stratification is a common feature of talus breccias which often grade laterally into finer grained and distinctly bedded sediments. Winnowing by bottom currents at the base of the fault scarp or into a fissure would account for the concentration of finegrained glass and mineral fragments.

Study of the morphology of the glass shards unequivocally suggests that they represent thermally shocked and cracked debris and are not pyroclasts generated by explosive processes. One might imagine that considerable amounts of such material is created by thermal shock and spalling during submarine eruptions of basaltic magmas on the rift floor when pillows and flows are formed. The lack of deuteric alteration or palagonitization of the glass in the sandstone, and sand and gravel suggests rapid isolation from altering action in combination with slumping and tectonic disruptions of pillow mounds would lead to the formation of sands from such material. In fact, winnowed sands appeared frequently in bottom photographs of the FAMOUS region (Brundage, personal communication, 1977) and elsewhere along the Mid-Atlantic Ridge (Heezen et al., 1959; Heezen and Hollister, 1964). The clastic zone in Hole 396B could result from rapid in-filling of a fissure or deposition of debris at the base of a fault scarp by current action and slumping, followed by a period of quiescence and carbonate sedimentation on the debris, subsequently covered by a later volcanic eruption. Such a sequence of events would seem predictable from the cyclic volcanism and ubiquitous faults and fissures found at the Mid-Atlantic Ridge in the FAMOUS region median valley.

The Core 33 sand and gravel is again different from those found in either Core 30 or Core 19 and is thought to consist largely of drilling debris. The reason for this interpretation is: (1) the drilling rate was the same as for basalt, (2) the sand has a high predominance of relatively crystalline basalt clasts similar to the Core 19 sand, and (3) the basalt clasts look like freshly crushed road material. The lack of microfossils as well as the different proportions and abundance of phenocrysts in the lithic clasts indicate that Core 33 sand and gravel were derived locally. This is suggested by the absence of weathered material similar to that recovered in Core 19. The high proportion of plagioclase relative to olivine phenocrysts (Figure 2) is also similar to that found in the phyric pillow basalt drilled in Core 32 , while the smaller abundance of phenocrysts in the Core 30 sand is similar to the phenocryst proportions in the overlying basaltic breccia talus. It might be argued that these differences are the result of sorting accompanying washing in the core liner during drilling, and core recovery of different size fractions. If this were the case, however, one would expect that for a given size fraction, the denser olivine would be concentrated in the coarser grained sand and gravel (Core 33, see Figure 1). In fact (as seen from Figure 3), olivine is concentrated, in proportion to plagioclase, in the finer grained sand and gravel (Core 30), and plagioclase is concentrated in the coarser grained sand and gravel (Core 33 ). The high proportion of glass in Core 33, however, may represent some in-filling and mixing of material from the sand unit penetrated in Core 30 . 
Until many more deep holes are drilled in the oceanic crust, the importance or ubiquity of material similar to the Hole 396B Core 30 sand and gravel cannot be known. Nonetheless, this material raises some interesting questions, particularly as to its abundance or occurrence in ophiolites. It is generally assumed that hydrothermal activity is ubiquitous at ocean ridges. This idea is suggested by several lines of evidence and proved by the direct observation of geothermal activity along ocean ridges at places such as the Galapagos spreading center. It is logical to think that hydrothermal activity within the oceanic crust would be localized along fractures and fissures, and in zones of poorly consolidated porous rubble, gravel, and sand. The presence (under $165 \mathrm{~m}$ of abyssal basalt) of poorly consolidated sandstone, sand, and gravel that are essentially unaltered, makes one wonder about the frequency of such hydrothermal activity along ocean ridges.

\section{REFERENCES}

DSDP Scientific Party, Leg 46, 1976. Glass-rich basaltic sand and gravel within the oceanic crust at $22^{\circ} \mathrm{N}$, Nature, v. 262 , p. 768-770.

Fox, P.J. and Heezen, B.C., 1965. Sands of the mid-Atlantic Ridge, Science, v. 159, p. 1367-1370.

Heezen, B.C., Tharp, M., and Ewing, M., 1959. The floors of the oceans. In The North Atlantic: New York (Geol. Soc. Am.).

Heezen, B.C. and Hollister, C.D., 1964. Marine Geol., v. 1, p. $1-141$.

Honnorez, J. and Kirst, P., 1975. Submarine basaltic volcanism: morphometric parameters for discriminating hyaloclastites from hyalotuffs, Bull. Volc., v. 33, p. 1-25.

Krumbein, W.C. and Pettijohn, F.J., 1938. Manual of sedimentary petrography, New York (Appleton-Century-Crofts, Inc.)

Niggli, P., 1952. Gesteine und Minerallagerstätten: Band II, Exogene Gesteine und Minerallagerstätten: Basel (Verlag Birkhäuser). 
PLATE 1

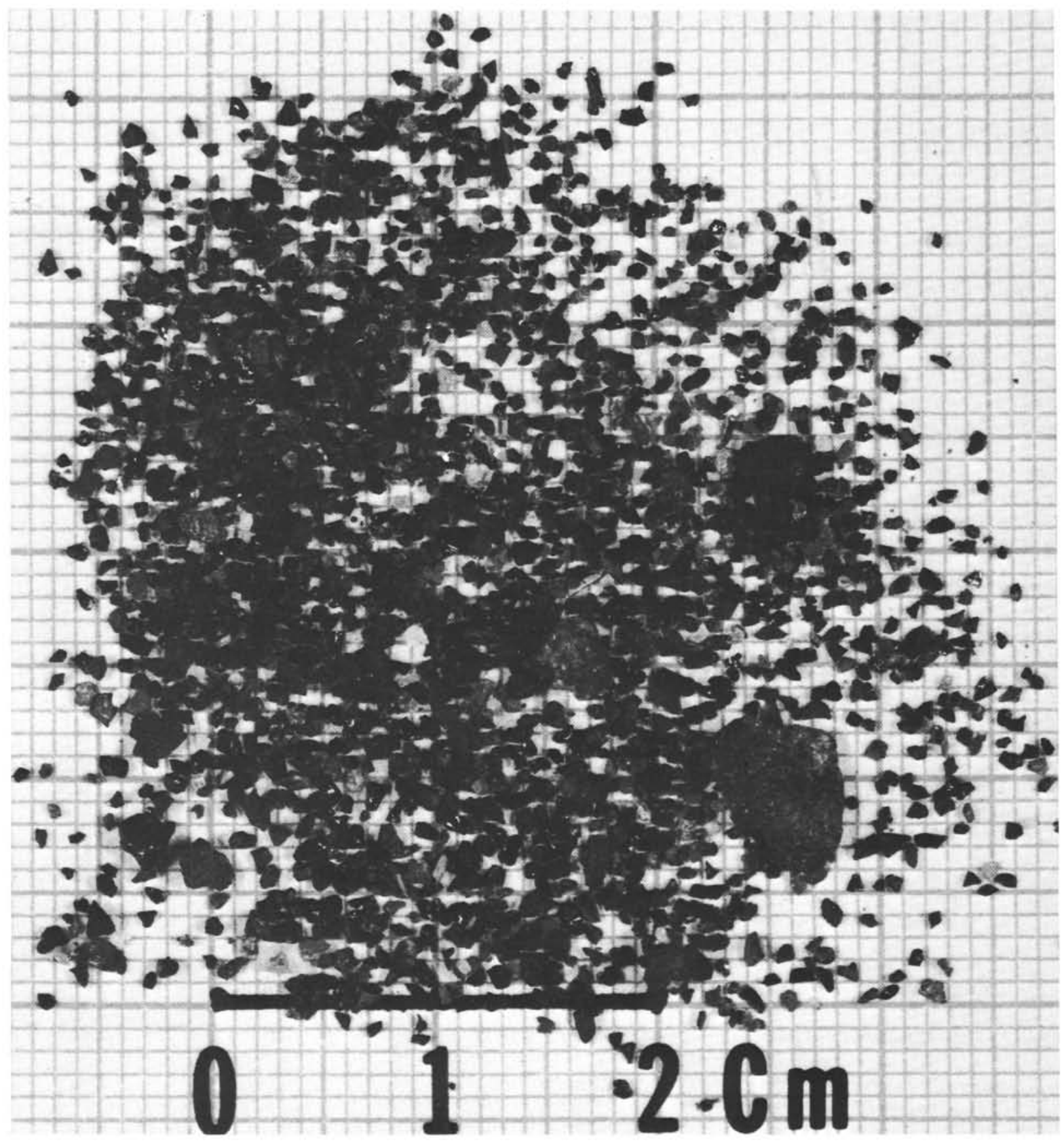

Photograph of the sand and gravel from Core 30, Unit 6. 
PLATE 2

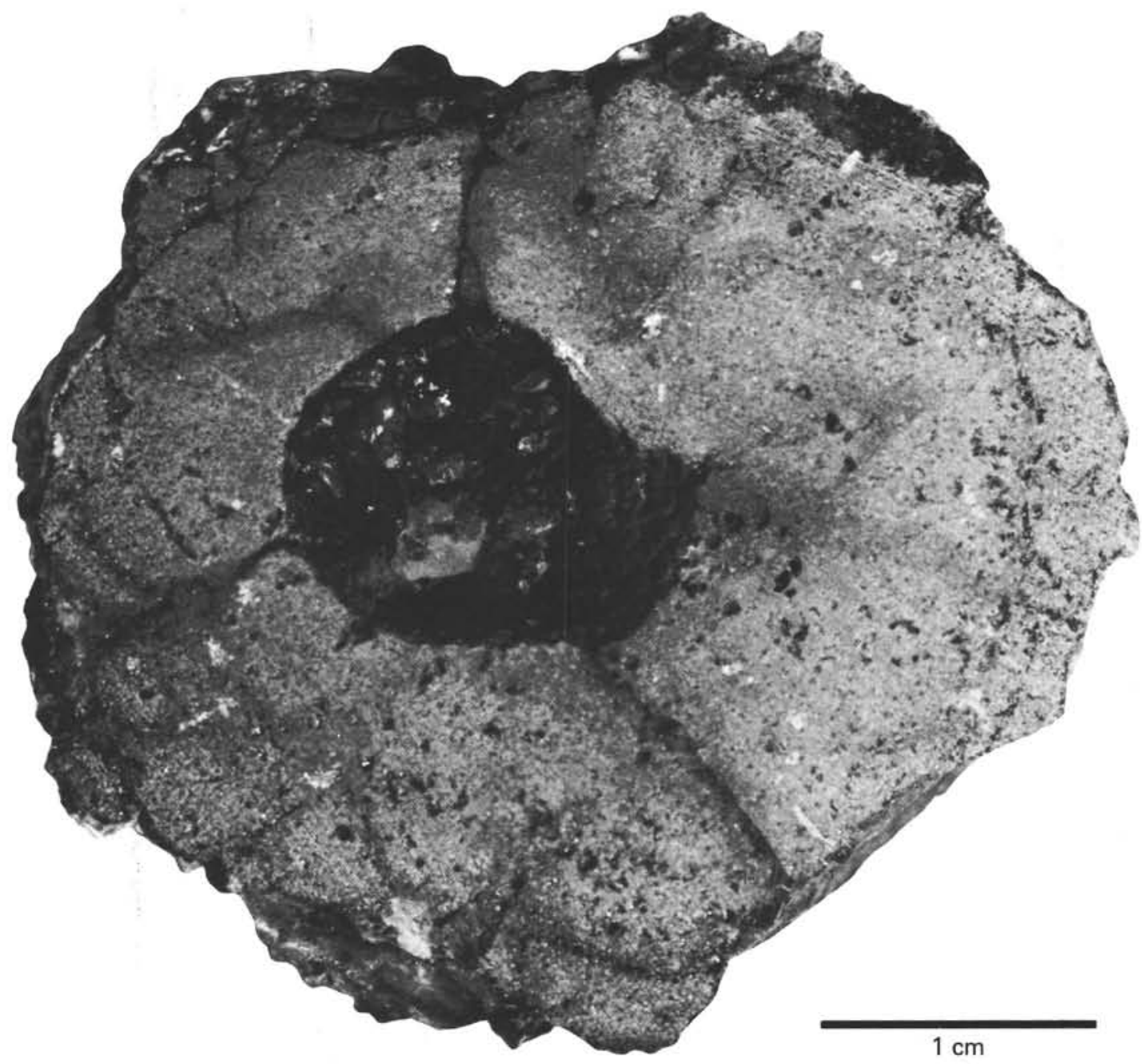

Photograph of the small pillow lava from Core 30, Unit 6.

PLATE 3

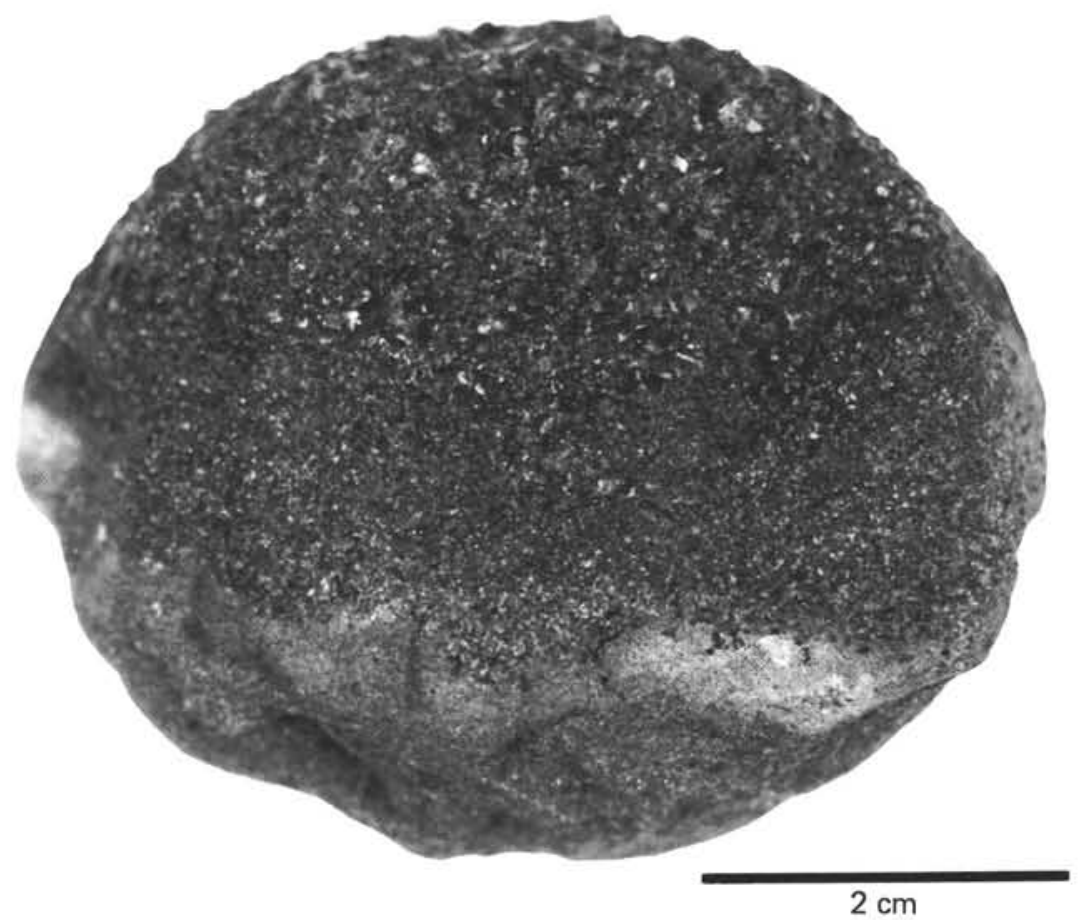

Photograph of the sandstone sample from Core 30, Unit 6 